\title{
Perception of Public Islam on Performance and Providing Public Services in Padangsidempuan City
}

\author{
Feriza Yetti Siregar \\ Universitas Islam Negeri Sumatera Utara \\ rerizasiregar@yahoo.com
}

\begin{abstract}
Public service is a matter that is closely associated with bureaucracy. Five factors are related to mission, accountability, consequences, power, and culture. Mission will determine the public services system competence in responding to dynamics that occur in the community accurately and efficiently. Method in this research was qualitative method, which was designed with descriptive research and phenomenology approaches through interviews and observations. Based on the research, the results showas follow: First, the perception of Islamic society in Padangsidimpuan on performance of Dinas Kependudukan dan Pencatatan Sipil (DKPS) in providing public services in 2014 was still far from their hope, and it hasn't met in their satisfaction category especially Islamic society. Second, factors that influence the achievement of DKPS Padang Sidimpuan in providing public services in 2014 are human resources and financial factors. Besides, there are some supporting factors: leadership, resources, culture ministry, institutional, and related regulation. Third, factor that hold up the performance of DKPS Padangsidimpuan in providing public services in 2014 is organization structure. The other factors are such as the lack of officers responding to society who need the information and the lack of officers' hospitality when they communicate to public. Fourth, the solution is given from Islamic society to improve public services at DKPS Padangsidimpuan for the next year: education, experiences, training, motivation to the staff and officer at DKPS Padangsidimpuan.
\end{abstract}

Keywords: Public Islam, Providing Public Services, DKPS, and Sidempuan City 
Abstrak. Pelayanan publik merupakan hal kaitannya dengan birokrasi. Ada lima faktor yang terkait dengan misi, akuntabilitas, konsekuensi, kekuasaan, dan budaya mereka. Misi tersebut akan menentukan kompetensi sistem pelayanan publik dalam merespon dinamika yang terjadi di masyarakat secara tepat dan efisien. Metode yang digunakan dalam penelitian ini adalah metode kualitatif, yang dirancang dengan penelitian deskriptif dan pendekatan fenomenologi melalui wawancara dan observasi. Berdasarkan hasil penelitian diperoleh hasil sebagai berikut: Pertama, persepsi masyarakat Islam di Padangsidimpuan terhadap kinerja Dinas Kependudukan dan Pencatatan Sipil (DKPS) dalam memberikan pelayanan publik pada tahun 2014 masih jauh dari harapan mereka, bahkan belum. tidak terpenuhi dalam kategori kepuasan mereka khususnya masyarakat Islam. Kedua, faktor-faktor yang mempengaruhi pencapaian DKPS Padang Sidimpuan dalam memberikan pelayanan publik tahun 2014 adalah faktor sumber daya manusia dan keuangan. Selain itu terdapat beberapa faktor pendukung yaitu kepemimpinan, sumber daya, kementerian kebudayaan, kelembagaan, dan regulasi terkait. Ketiga, faktor yang dapat menopang kinerja DKPS Padangsidimpuan dalam memberikan pelayanan publik pada tahun 2014 adalah struktur organisasi, dan faktor lain seperti kurangnya respon petugas terhadap masyarakat yang membutuhkan informasi dan kurangnya keramahan petugas saat berkomunikasi. kepada masyarakat. Keempat, solusi yang diberikan masyarakat Islam untuk meningkatkan pelayanan publik di DKPS Padangsidimpuan untuk tahun depan: pendidikan, pengalaman, pelatihan, motivasi kepada staf dan petugas di DKPS Padangsidimpuan.

Kata Kunci: Masyarakat Islam, Pemberian Pelayanan Publik, DKPS, dan Kota Sidempuan

\section{Introduction}

ervices of Dinas Kependudukan dan Pencatatan Sipil (DKPS) [the

DKPS] are classified as public services because of the public interest in the communities served by the City / Regency. The public interest in society is the main target in the delivery of public services. Officers from the Office of Population and Civil Registration as bureaucrats at the regional level are required to handle the obstacles faced in development efforts that are promoted by the government. The apparatus of the Population and Civil Registration Service Office must be able to carry out its main function, namely to provide services to the community properly, deftly, effectively, and efficiently. 
In this research, the public service is the service provided to the Muslim community in the city of Padangsidimpuan where the majority of people in the Padangsidimpuan embrace Islam. Because the Islamic community of Padangsidimpuan City expects Islamic services when dealing with the community because by being polite, good manners in Islam are highly recommended because when serving and providing good service and people who receive services feel happy, communication will be created. Which is good anyway, and that is what is actually expected.

The description above and based on the observations made by the author in the City of Padangsidimpuan, it shows that there are still complaints from the people of Padangsidimpuan City in dealing with service parties at the population and civil registration service of Padangsidimpuan City, especially the Islamic community in Padangsidimpuan City, among others: officers who are difficult to find at, there are still many people who do not know clearly about service procedures, especially the requirements that must be completed, making it difficult for the community when dealing. Because in Islam, there are important things that must be seen when providing services, such as being gentle when serving, speaking is part of a good serving strategy, and Allah also encourages his ummah to be gentle when speaking and serving. At the same time, the obstacles in service at the DKPS of the City of Padangsidimpuan are the procurement of office facilities and infrastructure that do not support performance in the service process, the lack of seriousness of the apparatus when dealing with the community when serving so that it slows down the process of providing services to the community.

\section{Theoretical Framework}

\section{a. Definition of Perception}

In his introduction to general psychology, Bimo Walgito explained that perception is the individual observing the outside world using his senses or a tangible process to receive a stimulus through his response (Walgito, 2004, 33). According to Jalaluddin Rahmat, in his book "Psikologi Komunikasi" (psychology of communication), perception is an experience about the object of an event or its relationship with that obtained by gathering information and interpreting (Rahmat, 2004, 51). In this study, the Muslim community perception of the Padangsidimpuan City population and civil registration service performance in providing 2014 public services.

b. Definition of Society

Society can be defined as a group of people who have their own identity that differentiates them from other groups and live in a particular area or area separately. This group, whether narrow or broad, has unity among those groups 
(Widjaja, 1986, 9). In this study, the community is Muslims from the Padangsidimpuan City, which consists of six districts. The researcher takes three districts from districts, namely: the people of Padangsidimpuan Utara, Padangsidimpuan Utara, Kecamatan Padangsidimpuan Selatan dan Kecamatan Padangsidimpuan Hutaimbaru. Because according to researchers, the community from the three sub-districts can represent the six sub-districts in Padangsidimpuan City. Because the majority of people in the city of Padangsidimpuan are Muslims.

c. Definition of Performance

The word performance or in English is called performance, which is often interpreted by scholars as "appearance", "performance", or "achievement" and can also be interpreted as something that has been done (results achieved). Performance is a work result that can be achieved by a person or group of people in an organization in accordance with their respective authorities and responsibilities in an effort to achieve the goals of the organization concerned legally, does not violate the law, and is in accordance with morals or ethics (Sabaruddin, 2015, 2). The performance referred to in this study is a performance that has Islamic nuances and is following the al-Qur'an and Hadith. Because in Islam, there is what is called a good work ethic in the view of Islam, everyone who works must have a good work ethic, and this work ethic is seen from the quality that is given when working.

d. Determining the Quality of Public Service in Islam

The Islamic concept teaches that in providing services from businesses that are carried out in the form of goods or services, do not give inadequate or unqualified quality, but quality ones to others. In Islam, it also has principles that must be possessed by every Muslim when working and in this research is working to serve the community, including:

1. The intention to work is to worship Allah

With good intentions and noble intentions because of Allah alone, the service provided to the community when serving will get maximum results, because every time starting a job must be started with the intention of Allah alone so that the service is carried out better and as expected. . That shows this is in Q.S. al-Dhāriyāt verses 56-57 which reads: "I did not create jinn and humans except to worship Me. I seek no provision from them, nor do I need them to feed Me". And also in Q.S. al-An'am/6: 162 which reads: "Say, "Surely my prayer, my worship, my life, and my death are all for Allah-Lord of all worlds".

The verses above are an order to work with the intention of only Allah, so with the above verse, if it is related to this research when working in a way to serve the community, it must be for Allah alone in order to get public service as expected by the community, and in accordance with the regulations existing 
laws in Indonesia. 2. Work is a mandate to prosper the universe. Serving work is a mandate to prosper the community so that people can enjoy the results of services from officials or officers in accordance with their respective fields. The argument that shows this is Q.S. al-Baqarah/2: 30 which reads: "Remember when your Lord said to the angels, "I am going to place a successive human authority on earth." They asked Allah, "Will You place in it someone who will spread corruption there and shed blood while we glorify Your praises and proclaim Your holiness?" Allah responded, "I know what you do not know."

The point of this verse is that humans are made inhabitants of the world rule and prosper the world. The Word of God above states that whoever cultivates the crops, he will enjoy the results there. Whatever he does, there will be rewarded there. Thus humans are required to know the purpose of their life and the secrets behind their creation. Humans were created by Allah to be servants of Allah, who lead nature, not to become servants of what He created (al-Qaradlawi, 1997, 312).

3. Purpose and Orientation

Works is as an investment good deeds for the joy of life in the hereafter as well the joys of living in the world are met balance physical and spiritual needs is obvious that the aim of every human being to work it is to meet every need in the world, but in the Islam, not only in this world are fulfilled but practices when in the world you can make the afterlife of every human being according to the desires of that human being. So, working in serving society properly according to Islamic teachings will get a reward in accordance with his practice in the hereafter. The evidence that shows this is Q.S. al-Qașaș/28: 77 which reads: Meaning: Rather, seek the reward of the Hereafter by means of what Allah has granted you, without forgetting your share of this world. And be good to others as Allah has been good to you. Do not seek to spread corruption in the land, for Allah certainly does not like the corruptors."

4. Looking for a lawful income is fardu (compulsory)

Seeking lawful work is mandatory for every one of His people because in a lawful way, the results obtained will be a blessing. It is haram for every human being to seek lawful work, not on a path that is pleasing to Allah.

5. Work in good fields and avoid everything that is forbidden dirty (heinous)

Like the previous principle statement, clean and clean work is highly recommended in Islam, and it is not allowed to do dirty or vile work, such as corruption, etc. Because this can harm yourself and others. The argument which states this is the Q.S. al-Mā'idah/5: 100 which reads: "Say, O Prophet, "Good and evil are not equal, though you may be dazzled by the abundance of evil. So, be mindful of Allah, $\mathrm{O}$ people of reason, so you may be successful." The point of the above verse is that the jewels from Allah and good food can be enjoyed in this 
world by believers and non-believers, while in the hereafter, it is solely for believers. .

6. Appoint and delegate work to the experts

Every job should be given to a person who is an expert in his field. When the job is given a mandate, not to a person in his field, the work will not run smoothly, and even if it runs smoothly, the results obtained will be far from expectations. The argument which states that this is the letter of Q.S. al-Nisā'/4: 5 which reads: Meaning: "Do not entrust the incapable among your dependants with your wealth which Allah has made a means of support for you - but feed and clothe them from it, and speak to them kindly. The meaning of the above verse is that a person who is not fully intelligent is an orphan who is not yet mature or an adult who cannot manage his belongings.

7. Paying zakat

After working and getting results or what is called a salary, a person must pay zakat on the salary he gets so that the salary he gets is a blessing when used. The argument that states this is the Q.S. al-Tawbah/9 verse 103, which reads: Meaning: "Take from their wealth 'O Prophet' charity to purify and bless them, and pray for them-surely your prayer is a source of comfort for them. And Allah is All-Hearing, All-Knowing. The purpose of zakat in this verse cleanses them from stinginess and excessive love for property. Another purpose of zakat is to nurture goodness in their hearts and develop their property. From the explanation above, it is clear that in Islam, there must also be principles that must be upheld by every citizen who works even though they are not included in the principles as citizens, but this principle should be instilled from the beginning because when Muslims have instilled this principle when given the belief that the Islamic State is ready physically and spiritually to be given trust, that is one way Islam shows that Islam is the majority religion in Indonesia. For that, there are indicators in Islam to see the quality that is given when serving the community, namely this attitude that must be possessed, including:

1. Reliable dimension with respect to the ability to provide the promised service reliably and accurately. Service will be said to be reliable if the agreement has been disclosed is achieved accurately. Trust in services in relation to time, accuracy and accuracy is what will foster consumer confidence in service providers.[13] In this context, Allah also wants each of His people to keep the promises that have been made and stated as stated in Q.S. al-Nahl/116 verse 91, which reads: Meaning: Honour Allah's covenant when you make a pledge, and do not break your oaths after confirming them, having made Allah your guarantor. Surely Allah knows all you do". From the explanation of the above verse, it can be concluded that Allah also encourages each of his followers to keep their promises when a service has 
targeted time and accuracy in completing the service. In this research, the service referred to is the service provided at the Padangsidimpuan City Education and Civil Registration Service.

2. The dimension of responsiveness relates to the willingness or willingness of employees to provide fast and appropriate service to consumers. The speed and accuracy of service with regard to professionalism. In the sense that a professional employee himself will be able to provide services appropriately and quickly. This professionalism is shown through its ability to provide services to consumers. From the explanation above, it is clear when the mandate is handed over to people who are not in their field, then the service will not run smoothly, and the institution will suffer losses. Not only the institution but the people who receive the service will feel disadvantaged because when the community service is no longer there That is where the real destruction is when the mandate is given to those who are not experts or in their field and when the community does not believe in the services provided. The assurance dimension (assurance) relates to the knowledge or insight, politeness, courtesy, the confidence of the service provider, and respect for consumers. Providing services that show politeness and gentleness will guarantee a sense of security for consumers and have an impact on the success of service providers (Sinambela, 2012, 45). In this regard, Q.S. Ali 'Imrān/3 verse 159 states that: “It is out of Allah's mercy that you 'O Prophet' have been lenient with them. Had you been cruel or hardhearted, they would have certainly abandoned you. So pardon them, ask Allah's forgiveness for them, and consult with them in 'conducting' matters. Once you make a decision, put your trust in Allah. Surely Allah loves those who trust in Him. From the explanation above, people receiving services also need a sense of comfort and safety when service officers are polite and gentle.

3. The empathy dimension (empathy) relates to employees willingness to care and give individual attention to consumers. This willingness is shown through relationships, communication, understanding, and attention to consumer needs and complaints. The manifestation of this empathy attitude will make consumers feel that their needs are satisfied because they are served well. The employee empathy attitude is shown through providing information services and consumer complaints, serving consumer transactions with pleasure, helping consumers when they experience difficulties in transactions or other matters regarding institutional services. Willingness to pay attention and help will increase consumer perceptions and positive attitudes towards institutional services. This will bring joy, satisfaction, and increase consumer loyalty. Following the explanation 
above, which is when service officers/employees are lighter and easier to provide information to the public, then the public will be more impressed with the services provided in one agency or in government institutions because at times people need information and it is given easily or can be obtained easily, it is not uncommon for the public to think that the services provided are good.

4. Tangibles dimension (physical evidence) can be in the form of physical facilities such as buildings, comfortable rooms, and other infrastructure. In the Islamic concept, service with respect to physical appearance should not show luxury. Facilities that make consumers feel comfortable are important, but they are not facilities that emphasize luxury. This statement, as stated in the Q.S. al-Takāisur/102 verses 1-5, namely: Meaning: Competition for more 'gains` diverts you 'from Allah', until you end up in 'your' graves. But no! You will soon come to know. Again, no! You will soon come to know. Indeed, if you were to know 'your fate' ${ }^{\urcorner}$with certainty, 'you would have acted differently ${ }^{\top}$.]

\section{Perception of Public Islam to Performance of DKPS}

The perceptions of Islamic community towards the performance of the Padangsidimpuan City population and civil registration service in 2014 can be perceived. They can be seen through five dimensions, along with their service indicators. Generally, if you look at the perceptions of the Muslim community on the performance of the population service and civil registration service of the City of Padangsidimpuan in 2014 on all dimensions and indicators of public services in the city of Padangsidimpuan. According to the dimensions and indicators that have been determined by the perception of the Islamic community from the five dimensions as follows:

Dimensions of Physical Evidence (tangibles)

a) The community considers that the condition of facilities and infrastructure in the official office is inadequate, such as people who are not comfortable going to the toilet so that people do not feel comfortable in the service room.

b) Socialization of information that has not been implemented properly, both between superior officials and employees in the public who priority services. For example, various information about the procedures, costs, and time to take care of population administration should be conveyed to the public, slowly, or even reach the public. So if those who are going to deal with the Population and Civil Registration Office of the City of Padangsidimpuan are people who do not know anything about services or about any kind of management, it will be difficult to take care of 
themselves. Because in the city of Padangsidimpuan, not all people are highly educated.

From the results of observations and the results of interviews with research informants, it was found that the community mostly complained about the service facilities and infrastructure at the Padangsidimpuan City. The service is considered not yet satisfying the hearts of the Islamic community of Padangsidimpuan City due to the insufficient service facilities and infrastructure used and is still considered inadequate. For the Islamic community of Padangsidimpuan City, public services still require a variety of facilities and infrastructure that are sufficient, although not luxurious, such as bathrooms or toilets. As a community with the majority of Muslims in the city of Padangsidimpuan when dealing at the Padangsidimpuan City, most people want comfort in service, maybe not only Islam is the religion that says cleanliness is part of faith. According to researchers, there are good facilities and infrastructure in the form of toilets or bathrooms that should be repaired to minimize public complaints in the following year.

Reliability

For the dimension of reliability, the indicators are timeliness, equal treatment, simplicity, and speed. The people of Padangsidimpuan, especially the Muslim community, often complain about the difference between the provisions (as stipulated in the regional regulation) and the reality on the ground. According to the provisions, the costs that must be incurred by the community in managing anything at the DKPS are free or free of charge, which is under Law No. 24 of 2013 concerning the management and issuance of population documents. The duration of processing population documents has also been regulated in Law No. 24 of 2013, which is a maximum of 2 weeks of service, but there is a policy of being 3 (three) days. However, in practice, the community still often pays the management fee, which is referred to by the service as a voluntary fee, and the fee is also uneven. There are people who pay voluntary fees, but it is determined how much to pay, but people are not asked for fees even though it is a type of fee voluntary. On the other hand, the specified time period is also not in accordance with the provisions unless there is an additional fee. Some people also do not have access to information about the procedures that must be followed.

One of the causes is the lack of public access, especially people in rural areas, to obtain information, either through printed media or other information. This condition is exacerbated by the limitations of official staff in conducting socialization and information to the public. From the results of the researcher interview with the Head of Services and Civil Registry Deeds at the Padangsidimpuan City, the researcher could observe from his statement that 
there are still people who manage their population documents through brokers or other people, and if that happens they should be the officers does not accept if it is not the person concerned who directly takes care of their Population documents, besides that the researcher also concludes that with his statement there are still incomplete requirements which should be when the community takes care of something there must go through the file preparation first, if the file is incomplete, so hopefully the public can complete it so it can be processed. So, from the statement that there are files that have been entered or received regardless of whether the requirements are complete or not, this statement is not much different from your informant's statement who hurt the previous Sitompul. However, it is not entirely what the Head of Services and the Civil Registration certificate have said is wrong because the regulations have been implemented in the respective. Still, the officers in the registration section are likely to be less careful about this. They can be corrected so that the community does not get too badly on their suspicions about officers.

Responsiveness

The dimension of responsiveness with indicators of the speed acceptance of suggestions and criticism, convenience, and adequate knowledge. From the indicators for suggestions and complaints of the Islamic community, the Padangsidimpuan City considers that employees can accept criticism and suggestions submitted by the community to them. On the other hand, the employee knowledge indicator indicates that employees are considered not all employees to have adequate knowledge about the field of work and services provided. People perceive that service has not been matched by sufficient knowledge of employees or officers.

\section{Confidence}

For the dimension of confidence with indicators of friendly, according to expectations, work culture, quality of results, responsibility, fairness, in accordance with provisions, and ability. The Islamic community of Padangsidimpuan City considers that there is still a lack of hospitality and is not following the expectations of the Islamic community of Padangsidimpuan City. Services are provided to employees or officers when serving the community. The quality of public services is not optimal in terms of the dimensions of belief. Padangsidimpuan City is caused by a). The services provided by officers or employees are not in accordance with work culture, lack of discipline, are weak in cooperation, lack of integrity, etc. b). Employees at work have not been oriented towards good results, quality of work, and service recipient's satisfaction.

In accordance with the results of interviews with the people of Padangsidimpuan City, to be precise, people in 3 Padangsidimpuan Districts 
were used as research locations. There are still many Padangsidimpuan City people who say the same thing that the researchers did not explain the explanation from the community one by one. There are also some people who say that if the leader comes to the office on time, the employees will not dare to come any longer. Employee reluctance must also be there if the leader or Kadis comes at the beginning.

Empathy

The dimension of empathy through interaction, adaptation, flexibility, willingness, and cooperation. According to the perceptions of the Islamic community of Padangsidimpuan City, the indicator of officers willing to listen to community complaints is considered good and can still receive complaints from the people of Padangsidimpuan City. However, not all employees or officers receive complaints from the community. But on the contrary, the indicator of willingness to cooperate and work together with the Islamic community of Padangsidimpuan City considers that employees or officers still lack in cooperation to work together in terms of serving the community in the office because not all employees or officers have the soul to work together to provide good services, some employees want to take care of and complete their own business. The dimension of Islamic belief that it teaches its people always to be friendly and cheap to smile, responsible when given trust, fairness to anything, and in any situation. Then, always a good work culture is upheld when working as in this study, the work culture in serving the community Islam. It also appears that from the dimension of empathy, Islam also teaches and requires that each of its followers always cultivate mutual cooperation so that whatever they want can run smoothly and well. Islam also teaches its followers a high sense of willingness to become better individuals in daily activities

\section{Factors of Actors Influencing the Performance of the DKPS}

According to the result of interviews with people of Padangsidimpuan City, which are precisely the people in the Padangsidimpuan Utara District, previously in the perception of the Islamic community this informant also said the same thing, namely: If the leader in the District Head Office is firm and respected by employees, all existing regulations are not $100 \%$ in place. Obey employees at least not detrimental to society, and if all employees arrive on time, we even the community will not have many demands on that person/officer. There are still many Padangsidimpuan City people who say the same thing that the researchers did not explain the explanation from the community one by one. There are also some people who say that if the leader comes to the office on time, the employees will not dare to come any longer; employee reluctance must also be there if the leader comes at the beginning. 
From several communities interviewed by researchers, researchers can conclude that the human resource factor/leader, which is the leader of human resources, greatly affects the performance of the DKPS's staff in providing public services in Padangsidimpuan City. Meanwhile, from the service culture factor, Allah also instructs every servant to provide every service when serving the best possible service because good service will please the heart, and when the service is also fair, there is no discrimination against the people who want to deal with it, that is what it wants. Islam. In addition, Islam's work attitudes have also been regulated in an honest, fair, responsible religion because Islam requires each of its followers to be honest. The human resource factor, Islam, also recommends that every leader must have quality in his field because this also includes human resources. The attitudes must be applied to every Muslim individual when working because with the work ethic in every Muslim, the agency that wants to recruit is not disappointed with Islam's quality. Institutional factors, each institution has its regulations and laws. Still, there is nothing wrong if the institution includes the work ethic regulations that each staff must have taken from the work ethic of Muslims because it will be better in the future, especially for the majority of people who There are followers of Islam in Indonesia and the city of Padangsidimpuan in particular.

\section{Factors Inhibiting Performance DKPS in Gives the Public Service}

While the inhibiting factor of public services is the most important of which is the organizational structure itself. According to researchers, when the organizational structure is not well organized, everything that is done and the results of public services will be less satisfactory because the basics alone are wrong, and the results obtained will also be messy. From several complaints or factors, according to the people of Padangsidimpuan City, the researcher can conclude that the public services at the Padangsidimpuan City DKPS are still classified as unsatisfactory and still need more improvement. When viewed from human resources, the main weaknesses are related to professionalism, competence, empathy, and ethics. Various views agree that one of the elements to consider is an appropriate compensation system. When viewed from the institutional side, the main weakness lies in the organization design, which is not specifically designed to provide services to the community, full of hierarchies that make services convoluted (bureaucratic) and uncoordinated. The tendency to carry out two functions simultaneously, the regulatory process and the administration function, is still heavily carried out by the government, causing public services to be inefficient.

\section{Solutions Provided by the Islamic Society}


The solutions mentioned by the Islamic Community might help improve the performance of the Padangsidimpuan City personnel. So, it will be better in the future because, according to the Islamic community of Padangsidimpuan City, the community solutions will be able to improve government bureaucracy in public services. , especially in the Office of DKPS of Padangsidimpuan City, and it can also be done to increase the professionalism of civil servants, among others, through education, training, experience and high work motivation for apparatus, namely civil servants or officers in the Service Office. Population and civil registration of Padangsidimpuan City. The solution given is in the form of: (a) Education, The provision of education for employees and officers at the DKPS, is highly expected by the Islamic community of Padangsidimpuan City to carry out their roles properly without disappointing the community. (b) Training according to the people of Padangsidimpuan City, the majority of whom are Muslims. Here are needed because without training, of course, government apparatus, be it civil servants or honorariums, at the Padangsidimpuan City DKPS Office will find it difficult to carry out their duties. They are given time to carry out training and practice in accordance with the education they had previously received. (c) Experience is the best teacher. That is one of the expressions mentioned by the people of Padangsidimpuan City, because according to the Islamic community, this is a proverbial expression that can be done to improve the performance of employees or officers at the Padangsidimpuan City DKPS Office because employees or officers who have more experience should be placed according to their abilities. So, he can lead inexperienced subordinates to properly carry out their duties and avoid the corruption practice that has been complained of by the people of Padangsidimpuan City in general and the Muslim community in particular. The problem of avoiding corruption is indeed difficult to do if there is no awareness of each individual. This can be suppressed by imposing the government heaviest sanctions so that all officials and levels of society are reluctant to carry out bad attitude. (d) Work motivation. According to the Muslim community, work motivation is needed for employees or officers at the Padangsidimpuan City DKPS Office. After getting an education, training, and a lot of experience. There is still a human side that needs to get encouragement so that they are enthusiastic about working. Encourage them to carry out their work in a professional manner. In addition, the demands of the community in the era of decentralization for quality public services will be even stronger from year to year. Therefore, government credibility is very much determined by its ability to overcome various problems so that it is able to provide public services that satisfy the community according to its capabilities. From some of the solutions that the researchers described above, the solutions provided by the people of 
Padangsidimpuan City also vary. Of the several solutions offered by the people of Padangsidimpuan City, this can hopefully be realized well because the community expectations are carried out well according to the community's expectations.

\section{Conclusion}

Based on the results of research and discussion related to the perceptions of the Padangsidimpuan City Community on the performance of the Padangsidimpuan City DKPS in providing public services for the 2015 Period, the following conclusions can be drawn: The perception of the Padangsidimpuan City Islamic Community on the Performance of the DKPS of the City of Padangsidimpuan in providing public services in 2014 is still unsatisfactory and is still far from the expectations of the Padangsidimpuan City Community, especially the Islamic community who lives in Padangsidimpuan Utara District, Padangsidimpuan Selatan and Padangsidimpuan Hutaimbaru District. Besides that, if seen from the perspective of the dimensions of physical evidence, reliability, responsiveness, confidence, and empathy for the public services provided to the Muslim community, it is also still low.

Factors that can affect the Performance of the DKPS of the City of Padangsidimpuan in Providing Public Services for the 2014 period are factors of human resources and financial factors, besides that there are also those who put forward different things, but some are the same, namely: leadership factors, factors resources, service culture factors, institutional factors, and related regulatory factors. Factors that can hinder the performance of the DKPS of Padangsidimpuan in providing public services for the 2014 period are organizational structure factors, and some have suggested inhibiting factors in public services. The solution provided by the Islamic society for advancing public services of DKPS office the following year, the solution provided by the community was in the form of solutions for providing education for employees or officers at the DKPS Office, providing training to employees or officers of the DKPS, the experience of employees or officers of the DKPS, providing motivation to officials or officers because with motivation to improve community performance they expect public services always good.

\section{References}

Departemen Agama RI, al-Qur'an dan Terjemahnya, Bandung: CV. Diponegoro, 2010.

Al-Qaradlawi, Yusuf, al-Sunnah, Masdaran li al-Ma'rifah al-Hadlarah, terjemah Abad Badruzzaman, Surabaya: Dunia Ilmu, 1997.

Rahmat, Jalaluddin, Psikologi Komunikasi, Bandung: Remaja Rosdakarya, 2004. 
Perception of Public Islam to Performance and Providing Public Services | 92

Sabaruddin, Abdul, Manajemen Kolaborasi dalam Pelayanan Publik: Teori,

Konsep dan Aplikasi, Yogyakarta: Graha Ilmu, 2015.

Sinambela, Lijan, Reformasi Pelayanan Publik, Jakarta: Bumi Aksara, 2012.

Walgito, Bimo, Pengantar Psikologi Umum, Yogyakarta: Andi Ofset, 2004.

Widjaja, A. W., Manusia Indonesia: Individu, Keluarga, dan Masyarakat, Jakarta: Pressindo, 1986. 